\title{
Global Media and Communication
}

http://gmc.sagepub.com/

\section{Mediating solidarity}

Natalie Fenton

Global Media and Communication 2008 4: 37

DOI: $10.1177 / 1742766507086852$

The online version of this article can be found at:

http://gmc.sagepub.com/content/4/1/37

\section{Published by:}

(S)SAGE

http://www.sagepublications.com

Additional services and information for Global Media and Communication can be found at:

Email Alerts: http://gmc.sagepub.com/cgi/alerts

Subscriptions: http://gmc.sagepub.com/subscriptions

Reprints: http://www.sagepub.com/journalsReprints.nav

Permissions: http://www.sagepub.com/journalsPermissions.nav

Citations: http://gmc.sagepub.com/content/4/1/37.refs.html

>> Version of Record - Mar 4, 2008

What is This? 


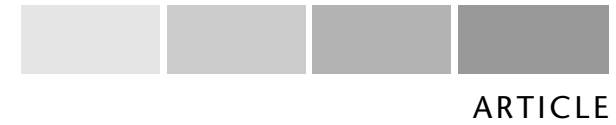

\title{
Mediating solidarity
}

\author{
Natalie Fenton \\ Goldsmiths College, University of London
}

\begin{abstract}
With the apparent increase in the number of alternative political media, political pluralists are again faced with the question: does the proliferation of subaltern counter-publics lead to a multiplication of forces? Fragmentation in political culture is fuelled by the rise of identity politics that focuses on consumption not production. Party allegiances and class alliances give way to more fluid and informal networks of action. Postmodern theorists celebrate fragmentation because it allows the recognition of diversity in political desires, acknowledges difference between individuals and debunks the myth of homogenous political units leading ultimately to liberation. But for political efficacy there must be more than the apparent freedom that comes with embracing difference and diversity. This article argues that if we accept the description of society as fragmented, in order to create a viable political community then solidarity is crucial. In a global economy, solidarity can be mediated through new communication technologies but the challenge is to articulate the politics online with actual movements and struggles on the ground.
\end{abstract}

KEY WORDS

mobilization - new communication technologies - new social movements solidarity

\section{Introduction}

This article considers the nature of political mobilization in an era of global communication. It addresses issues concerned with the internet and its relationship to New Social Movements (NSMs). ${ }^{1}$ In the age of the internet as more and more NSMs seek to organize and campaign online, this article reflects on whether or not the internet can bring about a new form of political activism, with consequences for the way we conceive of and carry out our political citizenship. The internet is now home to a multitude of groups dedicated to objecting to and campaigning against particular issues and politics. These public communications online have

Global Media and Communication [1742-7665(2008)4:1] Volume 4(1): 37-57 
been argued to be part of the process of realizing the public sphere - a space where democracy can be enacted - allowing us to analyse how shared democratic values and identification as democratic citizens are achieved and maintained; how political/civic cultures are generated essentially, to imagine how civil society can organize democratically for politically progressive ends (Habermas, 1989, 1992; Downey and Fenton, 2003; Fenton and Downey, 2003). Through these forms of online activism, the internet has become a home to mediated activity that seeks to raise peoples' awareness, give a voice to those who do not have one, offer social empowerment, allow disparate people and causes to organize themselves and form alliances, and ultimately be used as a tool for social change.

Online political mobilization falls under the general banner of alternative media. In its most basic sense this refers to the internet as a space for the expression of views excluded from the mainstream media. For Negt and Kluge back in 1972, media practice that was alternative to the mainstream media in content and forms of production was a response to dominant capitalist communications. They saw the formation of counter-publics in alternative media practice as offering forms of solidarity and reciprocity grounded in a collective experience of marginalization. To enable changes in society they argued that counterpublics must form alliances and make connections with other publics and other types of publicity. Once this is achieved, they can then take advantage of the opportunities that arise in the mainstream media or dominant public sphere to better advance their cause(s). This article explores this approach for a preliminary analysis of the role of the internet in popular mobilization and its potential for facilitating transnational protest and oppositional politics. It foregrounds the importance of issues relating to both structural, socio-economic factors and the individual issues of agency and collectivism considered in the context of the aesthetics and form of the technology and the nature of New Social Movements.

This article also seeks to consider a key question for political pluralists in the digital age. As the creation of counter-publics online appears to increase in number does their proliferation lead to a multiplication or fragmenting of forces? Some argue that unless powerful efforts at alliances are made, the oppositional energy of individual groups and subcultures may be neutralized in the marketplace of multicultural pluralism or polarized in a reductive competition of victimizations. There may also be problems of control, decision-making, accountability and collective identity (Gamson, 1990; Klein, 2002). 
The polar view is that the multiplicity of groups and ideologies present online allows the growth of much broader networks creating a vast web of oppositional politics. The multiplicity of oppositional groups found online has been celebrated by postmodern theorists because it allows the recognition of diversity in political desires, can acknowledge difference between individuals and debunk the myth of homogenous political units. But it has also been argued that for political efficacy there must be more than the apparent freedom that comes with embracing difference and diversity.

Here I suggest that if we accept the description of society (online and offline) as fragmented, solidarity is crucial in order to create a viable political community. Solidarity is the necessary condition and the essential collective contribution to the well-being of liberty and difference the one thing the postmodern condition is unlikely to produce on its own without a political intervention (Bauman, 1997). In a global economy forms of media such as the internet, that can operate at once both transnationally and outside of, or at least alongside, the corporate reach of multinational commercial media, may provide the means by which global solidarity can be relayed.

\section{Popular mobilization and the internet: multiplicity and polycentrality}

Naomi Klein (2000) argues that the internet facilitates international communication among non-governmental organizations (NGOs), and thus allows protesters to respond on an international level to local events while requiring minimal resources and bureaucracy. This may be through the sharing of experience and tactics on a transnational basis to inform and increase the capacity of local campaigns. According to Klein, the internet is more than an organizing tool. It is also an organizing model for a new form of political protest that is international, decentralized, with diverse interests but common targets. These themes of multiplicity and polycentrality recur throughout the literature and are assessed both negatively and positively.

Salter (2003) claims that the internet is a novel technological asset for democratic communications because of its decentred, textual communications system, with content most often provided by users. On this basis it accords with the requisite features of New Social Movements that have grown out of a decrease in party allegiances and class alliances. NSMs are more fluid and informal networks of action than the class and party politics of old. They are based in, but spread beyond, localities and 
are usually non-hierarchical, with open protocols, open communication and self-generating information and identities. Such networks are often staunchly anti-bureaucratic and anti-centralist, suspicious of large organized, formal and institutional politics. In turn, the fragmentation of political culture is fuelled by the rise of identity politics that recognizes diversity and allows for differentiated notions of citizenship among diverse counter-publics. New Social Movements share common characteristics with web-based communication: they lack membership forms, statutes and other formal means of organizing; they may have phases of visibility and phases of relative invisibility; NSMs may have significant overlaps with each other and are liable to rapid change in form, approach and mission. Furthermore, the ability of new communication technologies to operate globally and respond to global economic agendas in a swift and timely manner is key to their contemporary capacity to mobilize against the vagaries of global capital.

One much quoted example is the anti-globalization movement that gained public recognition at what is now commonly referred to as 'The Battle of Seattle'. On 30 November 1999 an alliance of labour and environmental activists congregated in Seattle in an attempt to make it impossible for delegates to the World Trade Organization (WTO) conference to meet. They were joined by consumer advocates, anticapitalists and a variety of other grassroots movements. Simultaneously, it is claimed that nearly 1200 non-governmental organizations (NGOs) in 87 countries called for the wholesale reform of the WTO, many staging their own protests in their own countries (The Guardian Online, 25 November 1999, p. 4). Groups integrated the internet into their strategies. The International Civil Society website provided hourly updates about the major demonstrations in Seattle to a network of almost 700 NGOs in some 80 countries (Norris, 2002). The demonstration was heralded as a success for transnational internet activism. A large part of this success was attributed to the characteristics of multiplicity and polycentrality.

\section{Popular mobilization and the internet: interactivity and participation}

Multiplicity and polycentrality assume and often encourage connectedness across both borders and issues. The more this trans-border traffic intensifies, the more the internet impacts upon the internal organization of the social movement organizations through forging alliances and coalitions across different movements, sharing best 
practice and most effective campaign techniques that can change the way groups organize and operate. Similarly, the protest activity and alliances of social movements on the ground can impact upon the way in which the internet is used and structured on the various and multiple websites. In other words interactivity is both between groups and between online and offline forms of organizing.

For example, the People's Global Action (PGA) organization, formed in 1998 by activists protesting in Geneva against the second Ministerial Conference of the WTO, and to celebrate the 50th anniversary of the multilateral trade system (GATT and WTO) is an attempt to create a worldwide alliance against neo-liberal globalization on an anti-capitalist platform. It is defined as 'an instrument for communication and coordination for all those fighting against the destruction of humanity and the planet by capitalism, and for building alternatives' (www.agp.org, March 2006).

So far, the PGA's major activity has been coordinating decentralized Global Action Days around the world to highlight the global resistance of popular movements to capitalist globalization. The first Global Action Days, during the second WTO ministerial conference in Geneva in May 1998 involved tens of thousands in more than 60 demonstrations and street parties on five continents. Subsequent Global Action Days have included those against the G8 (18 June 1999), the third WTO summit in Seattle (30 November 1999), the World Bank meeting in Prague (26 September 2000), the fourth WTO summit in Qatar (November 2001). The PGA describes itself as an instrument for coordination, not an organization, and its main objectives are:

- inspiring the greatest possible number of persons and organizations to act against corporate domination through civil disobedience and people-oriented constructive actions

- offering an instrument for coordination and mutual support at global level for those resisting corporate rule and the capitalist development paradigm

- giving more international projection to the struggles against economic liberalization and global capitalism, as well as to the struggles of indigenous people and original cultures (PGA, March 2006).

The capability of the internet to speed up and increase the circulation of struggle, to facilitate interactivity and participation is the raison d'etre of the PGA, and has been argued to be key to the success of 
many campaigns that rely on the internet (Cleaver, 1999). This online circulation of struggle benefits from perceived decentralization and autonomy of individual groups/campaigns that are at once inclusive and diverse but produce a high degree of identification among politicized citizens of the web. Encouraging participation in campaigns and protests goes hand-in-hand with the practice of interactivity.

A site formed by various NGO and civil society networks - The Association for Progressive Communications (APC) - describes itself as, 'the first globally interconnected community of ICT users and service providers working for social and environmental justice'. They state:

The Association for Progressive Communications is a global network of nongovernmental organizations whose mission is to empower and support organizations, social movements and individuals in and through the use of information and communication technologies to build strategic communities and initiatives for the purpose of making meaningful contributions to equitable human development, social justice, participatory political processes and environmental sustainability. (APC, March 2006)

In 2006, the APC had 36 member networks serving more than 50,000 activists, non-profit organizations, charities and NGOs in over 133 countries, with a strong mix of southern and northern organizations. These large, decentralized and often leaderless networks facilitated by new communication technologies operate a form of politics that is based on the participation of all citizens rather than the hierarchical model of traditional politics. 'Moreover, the essence of politics is considered the elaboration of "demands and responses" - constructing identities rather than "occupying power"' (Della Porta, 2005: 201). The act of participation itself and engagement with a particular issue is the political purpose rather than social reform or direct policy impact. Participation can, of course, be both online and offline. But the online participation is often about moving people to action offline. It is about building relationships and forging community rather than simply providing information (Diani, 2001).

Participation in New Social Movements has also been linked to disengagement with traditional party politics. In her extensive interviews with, and questionnaires to, activists Della Porta (2005) discovers a relationship between mistrust for political parties and representative institutions and very high trust and participation in social movements. The distinction between institutional politics and social movements rests upon the former acting as bureaucracies founded upon delegation of representation and the latter being founded on participation and direct engagement. This encourages us to move away from the notion of 
participative, deliberative democracy being realizable only through the traditional political structures of the nation-state. If we think in terms of a decentred, polycentric democracy and reject the modernist version of a political project with a single coherent aim of social reform then 'a more fluid and negotiable order might emerge, with plural authority structures along a number of different dimensions rather than a single location for public authority and power' (Bohman, 2004: 148) for governance. The internet in Benkler's (2006) analysis has the potential to change the practice of democracy radically because of its participatory and interactive attributes. It allows all citizens to alter their relationship to the public sphere, to become creators and primary subjects, to become engaged in social production. In this sense the internet is ascribed the powers of democratization.

\section{Popular mobilization and the internet: critical context}

Despite the optimism that surrounds the above appraisals that focus largely on exploring potential use of the internet as a free global space for social dialogue and transnational activism there are of course forceful counter arguments that can be categorized into three general themes: (1) statutory/government restrictions of use; (2) structural forces of capital organized either nationally or globally; and (3) the problems of fragmentation. All of these challenge the brave new claims for internet activism.

\section{Statutory/government restrictions}

Although the internet can be particularly important under authoritarian regimes, where protest activities and independent news media are severely constrained there are examples where the authorities have effectively blocked and suppressed activity within their own borders (for example, websites maintained by sympathizers of the Falun Gong in China and anti-state dissidents in Cuba) (Zhao, 2003). The Chinese Government is reported to employ around 30,000 internet police to control the web so that it can be used by businesses and not by its political opponents (The Guardian, 15 June 2005, p. 14). There is also restrictive practice in non-authoritarian regimes. On 7 October 2004 two servers located in London and hosted by Rackspace Managed Hosting, a San Antonio-based internet hosting company that provides dedicated servers to customers, were seized by European law enforcement agencies. Rackspace provides two dedicated servers, supplying the data centre, hardware (servers and other devices) and internet connectivity necessary 
to operate an online service, but allows the customer to directly operate the machines. The servers hosted independent online news service Indymedia's internet radio station and more than 21 Indymedia websites, as well as several email lists. Independent Media Centers (IMCs) are autonomous nodes of Indymedia, a collective of independent media organizations and thousands of journalists offering grassroots, non-corporate coverage of news events. Independent Media Centers claim to publish information often missed by mainstream media organizations, and to offer alternative perspectives on world events. The seizure was in response to a 'Commissioner's Subpoena' issued originally by the Italian police authorities. Rackspace said in a statement that their action was 'in compliance with a court order pursuant to a Mutual Legal Assistance Treaty (MLAT)'. These treaties establish procedures for countries to assist each other in investigations regarding international terrorism, kidnapping and money laundering. A few days later the servers were returned. As such news services increase in popularity it is likely that attempts to foreclose their activities will increase.

\section{Structural forces of capital}

Arguments concerning the use of new communication technology for linking oppositional groups, informing and facilitating local, national and international protest also come up against the structuring forces of national/global capital. These have been documented in various ways and include the following propositions:

1 More developed nations have been able to use modern communications technology to conduct business and represent their economic interests and cultural values worldwide (e.g. Schiller, 1989) leading to a worldwide hegemony of corporate ideology, speech and activity that accords with the pre-eminence of the transnational corporation.

2 Capitalizing on communications also falls not only to rich countries but to rich individuals in poor countries who enjoy far greater access to technology, allowing them to watch international television via satellite or conduct business with a cellular phone (e.g. Waters, 1995).

3 In the rich industrialized countries new communication technologies are central to the integration of business activities as well as to the production of commercial culture. Their increased use and development depends largely on private investment and 
competition. These rarely go hand-in-hand with open access and universal service (e.g. Sassen, 2005).

4 As the owners of the wires merge with Internet Service Providers (ISPs), gatekeepers to the net design the software we use to browse it, and all the big players get together to make content-sharing and affiliation deals, the vast array of information on the net becomes harder and harder to access. Just as in old media, the alternative voices can only be found if you know where to look and it requires substantial stamina and cultural capital to access this confusing multitude of communicators (e.g. Atton, 2004).

5 Finally and critically, by 2006 a very small percentage of the global population actually had access to the internet at all, with more than a quarter of the world's population with no access to electricity (World Energy Outlook, 2002).

\section{Problems of fragmentation}

The notion of multiplicity of oppositional groupings and diversity of people, politics and protest welcomed by some can also be approached from a very different perspective and interpreted as fragmentation, adding political confusion, increasing divisions and abetting individualism. For Castells (1996), the globalization of the capitalist system does not open up the possibility of a labour-led emancipatory project. In his view, the network society results in labour becoming localized, disaggregated, fragmented, diversified and divided in its collective identity. Taking Castells' view, the fragmented nature of new media does limit the capacity of New Social Movements to create coherent strategies due to the increasing individualization of labour. Problems of quantity and chaos of information challenge the way analysis and action are integrated in decision-making processes as well as existing configurations of power and collective identity in social movement organizations. Non-hierarchical forms of disorganization that make decisions on the basis of collective consensus become harder to achieve the larger and more disparate the collective.

Furthermore, the internet may contribute to the fragmentation of civil society, as well as political mobilization and participation. Habermas registers his ambivalence towards new information and communication technologies as a potential source of equal and inclusive communication:

Whereas the growth of systems and networks multiplies possible contacts and exchanges of information, it does not lead per se to the expansion of an 
intersubjectively shared world and to the discursive interweaving of conceptions of relevance, themes, and contradictions from which political public spheres arise. The consciousness of planning, communicating and acting subjects seems to have simultaneously expanded and fragmented. The publics produced by the internet remain closed off from one another like global villages. For the present it remains unclear whether an expanding public consciousness, though centered in the lifeworld, nevertheless has the ability to span systematically differentiated contexts, or whether the systemic processes, having become independent, have long since severed their ties with all contexts produced by political communication. (Habermas, 1998: 120-1)

Greater pluralism is regarded by Habermas as a risk for deliberative democracy rather than its saviour. This concern is echoed by Sunstein, who argues that the internet has spawned large numbers of radical websites and discussion groups allowing the public to bypass more moderate and balanced expressions of opinion in the mass media (which are also, he argues, subject to fragmentation for essentially technological reasons). Moreover, these sites tend to link only to sites that have similar views (Sunstein, 2001: 59). Such findings are supported by other empirical work, such as Hill and Hughes (1998). Sunstein argues that a consequence of this is that we witness group polarization (2001: 65) and this is likely to become more extreme with time. Sunstein contends that two preconditions for a well-functioning, deliberative democracy are threatened by the growth of the internet and the advent of multi-channel broadcasting. First, people should be exposed to materials that they have not chosen in advance. This results in a reconsideration of the issues and often recognition of the partial validity of opposing points of view. Second, people should have a range of common experiences, in order that they may come to an understanding with respect to particular issues (Downey and Fenton, 2003).

Sunstein also recognizes that 'group polarization helped fuel many movements of great value - including, for example, the civil rights movement, the antislavery movement, and the movement for sex equality' (2001: 75). One could argue that the internet may foster the growth of transnational enclaves of great value (for example, the environmental movement), but their value depends ultimately on how influential these enclaves become in the formation of public opinion beyond the radical ghetto. Through investigating only the texts of the internet sites themselves Sunstein falls prey to textual determinism that is challenged by Benkler (2006) who cites empirical research that shows that politicized internet users routinely cross-check internet sites that may clash with their own views. 
Although it may facilitate mobilization, the democratic potential of the internet is not dependent on its primary features of participation and interactivity, multiplicity and polycentrality, which are often celebrated and heralded as offering intrinsic democratic benefit. Democratic potential is realized only through the agents who engage in reflexive and democratic activity. It is an enabling device that is as susceptible to the structuring forces of power as any other technology. 'It is false to say that individuals possess immediate control; they have control only through assenting to an asymmetrical relationship to various agents who structure the choices in the communicative environment of cyberspace' (Bohman, 2004: 142). As Atton notes:

[T]o consider the internet as an unproblematic force for social change is to ignore the political and economic determinants that shape the technology; it is to pay little attention to how technological 'advances' may be shaped or determined by particular social and cultural elites (corporations, governments); and it is to ignore the obstacles to empowerment that legislation, inequalities of access, limits on media literacy and the real world situation of disempowerment necessarily place on groups and individuals. (2004: 24)

Claims for the extension and re-invention of activism need to be considered in the context of the material social and political world of inequality, injustice and corporate dominance. If it is true that a global civil society is developing on the web it is one that is segmented by interest and structured by inequality. The pre-eminent usage of global communication networks remains the efforts of corporations and governments to strengthen the dominant economic regime. The online world is firmly anchored in the offline world in terms of the social constraints all participants are subject to. Issues of cultural and economic capital are ever prevalent. The ability to define and shape the nature of any movement often falls to those with the necessary social and educational resources. Many of the high-profile protests take place at distant locations - only those protestors with funds for travel can get to them. And as these protests are often organized on the internet, the economic and cultural resources involved in the use of this technology also exclude many potential participants, probably those suffering the most impact from the very thing being protested against (Crossley, 2002).

What such critical analyses teach us is that the freedom to establish alternative voices is severely restricted within capitalist society. But we should not assume that closure is total. There are multiple ways of conceptualizing resistance and multiple ways of resisting. Despite the negative assessment above, impressive numbers of activists who use the 
internet have found creative ways to communicate their concerns and to contest the power of corporations and transnational economic arrangements, from fair-trade organizations and practices, deforestation in Brazil, attempting to stop ships from exporting toxic waste to developing countries, or the cancellation of debt for impoverished nations. Whether the margin of unpredictability, disjunction and improvisation has increased with the 1980s turn to a post-Fordist economy of cultural diversification, or whether it is rendered irrelevant by the concomitant move towards ever greater privatization, remains a crucial and open question. The tension between the relations of structure and agency are framed within overarching concerns of the nature and role of opposition within contemporary bureaucratic neoliberal states.

\section{Mediated solidarity?}

The problem, it would seem, however we approach it, is how fragmented and multiple oppositional groupings can function together for political ends. This is an issue that the feminist movement has grappled with and it is helpful to return to this debate. The diversity and multiplicity of identity that postmodernism embraces has been viewed variously within feminist thinking as: an unprecedented opportunity for women to forgo fixed identities and explore fluid subjectivities; an escape from the Enlightenment's establishment of methods of reasoning that were essentially male; or as a cultural movement that stifles the possibility for meaningful action just as feminism is beginning to make a political and social impact. What is claimed to be at stake in abandoning modernity as an enabling structure is the fear of losing the notion of the women's movement, losing the idea of what it is to be a woman, and losing with this a politics of representation. If women cannot be characterized in any general way, how can feminism be taken seriously? If we must forfeit the category 'women' for the sake of philosophical sophistication, what political grounding does feminism have? The issues hinge around the need to acknowledge and work with difference while also progressing a unifying political project. At the centre of this debate between modernist and postmodernist thought is the difference between essentialist and non-essentialist feminism, the conflict between objectivism and relativism and the push towards thinking in terms of either gender equality or of gender difference. Each of these issues cuts across the connection between universalism (what it means to speak about, and on behalf of, 'women') and a politics of change (that recognizes material 
inequalities that may be based on gender). As feminist theorists have noted (Braidotti, 1991; Spivak, 1992; Fenton, 2000), for political efficacy there must be more than the apparent freedom that comes with embracing difference and diversity, more than just an increase of instances of mediated protest or opposition.

In creating transborder politics there will always be difference. The feminist debate alluded to above suggests that even if we accept the possibility for fragmented and multiple oppositional groupings that can create their own political interventions via the internet, we still have to broach the next stage: how will a politics of solidarity in difference be realized? Social solidarity can be described as a morality of cooperation, the ability of individuals to identify with each other in a spirit of mutuality and reciprocity without individual advantage or compulsion, leading to a network of individuals or secondary institutions that are bound to a political project involving the creation of social and political bonds such as the anti-globalization movement. Mouffe (1992, 1993) asserts the need for a framework agreement of political values or a grammar of political conduct to provide the foundations for citizen engagement. There must be a commitment to the value of difference that goes beyond a simple respect and involves an inclusive politics of voice and representation. It also requires a non-essentialist conceptualization of the political subject as made up of manifold, fluid identities that mirror the multiple differentiations of groups. Chosen identities at any one time can not be taken as given or static - political identities emerge and are expressed through an ongoing social process of individual and collective identity formation. In this manner social solidarity can be augmented.

Such mediated solidarity is evident in the research of social movement theorists. Della Porta and Tarrow (2005: 237) refer to the interconnections between online and offline participation as: 'rooted cosmopolitans' (people and groups rooted in specific national contexts but involved in transnational networks of contacts and conflicts); 'multiple belongings' (activists with overlapping memberships linked with polycentric networks); and 'flexible identities' (characterized by inclusiveness and a positive emphasis on diversity and crossfertilization). Participants in these movements are drawn together by common elements in their value systems and political understandings, and hence by a shared belief in narratives that problematize particular social phenomena (Keck and Sikkink, 1998; della Porta and Diani, 1999).

Mansbridge (2001: 240-1) argues that oppositional consciousness requires identifying with an unjustly subordinated group, recognizing a 
group identity of interest in doing so, understanding the injustice as systemic, and accepting the need for, and efficacy of, collective action. She also states that the formation of an oppositional culture is both an additive and an interactive process (2001: 249), where a variety of motivations are at play within the group. The use of the internet facilitates the diffusion of identities and the circulation of struggle. The internet encourages 'affinity groups' (i.e. 'self organized, self governing groups based on a commonality of values and interests') (Della Porta and Diani, 2006). These groups make a virtue and a philosophy out of their disorganized alliances that reject the traditional, institutional organized politics of old. This is viral solidarity - a techno politics of the information age (Jordon and Taylor, 2004). It is also part of what Tomlinson refers to this as 'complex connectivity': 'By this I mean that globalization refers to the rapidly developing and ever-densening network of interconnections and interdependences that characterize modern social life' (Tomlinson, 1999: 2). Computer-mediated solidarity is not linear; it does not follow a prescribed narrative:

These initiatives proceed without central focus. They constitute a diffuse coalescence of microactivisms contesting the macrologic of capitalist globalization ... They exist as a sort of fine mist of international activism, composed of innumerable droplets of contact and communication, condensing in greater or lesser densities and accumulations, dispersing again, swirling into unexpected formations and filaments, blowing over and around the barriers dividing global workers. (Dyer-Witheford, 1999: 157)

One example is the Dissent! network that was formed to provide a means of coordinating radical resistance to the G8 Summits. ${ }^{2}$ The network was formed in the autumn of 2003 by a group of people who had previously been involved in radical ecological direct action through Peoples' Global Action (discussed above). The network has no central office, no spokespeople, no membership list and no paid staff. It exists as a diffuse network for communication and coordination between local groups and individuals involved in building resistance to the G8, and associated campaigns. Dissent! is open to anybody willing to work within the Hallmarks of Peoples' Global Action (see www.agp.org).

OneWorld is another example of an online community of over 750 organizations, covering the whole spectrum of development, environmental and human rights activities and extending from Manhattan to Delhi. OneWorld is a vast news and information service. In 2002 the super site OneWorld.net carried over 1.5 million pages of text, images, video and sound and delivered them to millions of people around the world. Edited in eight OneWorld centres across the globe and updated 
24 hours a day, OneWorld.net also has the web's premier search engine on global justice, allowing users to find the content they want on the issues that matter most to them. Partner organizations range from global institutions like CARE and UNICEF to grassroots projects in the south tackling local hardship. They all use OneWorld.net to share ideas, to reach the public, to express solidarity and to take part in the global debate about the future of the planet and its peoples.

Solidarity expressed through new communication technologies can embrace a thousand fragmented subjectivities and 'say[s] something that transcends their particularity and speaks to us all' (Melucci, 1996: 1). The dialogic and globalizing characteristics of new communication technologies do not eradicate difference but can be said to promote political consciousness, reflexivity and agency:

To identify with a movement also entails feelings of solidarity towards people to whom one is not usually linked by direct personal contacts, but with whom one nonetheless shares aspirations and values. Activists and movement sympathizers are aware of participating in realities which are much vaster and more complex than those of which they have direct experience. It is in reference to this wider community that the actor draws motivation and encouragement to action. (Della Porta and Diani, 2006: 95)

The mediated world that embraces fragmented political subjectivities connects with the material world at the site of conflict, bringing together disparate experiences of political reality and finding common ground, though that ground may be uneven, contested and complex.

As Rheingold (2002) notes, advances in personal, mobile informational technology are rapidly providing the structural elements for the existence of fresh kinds of highly informed, autonomous communities that coalesce around local lifestyle choices, global political demands and everything in between. These multiple networks of connected citizens and activists link diverse communities, providing the basis for the possibility of a new politics of alliance and solidarity to overcome the limitations of postmodern identity politics (Bennett, 2004).

On this analysis it would seem reasonable to support the claim that new forms of mediation have revealed new forms of protest. But we must be ever wary of falling prey to techno-determinism. Mediated solidarity is far more than signing an online petition or clicking on protest websites while alone in your own home. Breslow (1997) argues that the internet promotes a sense of sociality, but its anonymity and lack of spatiality and density may be counterproductive to solidarity. Similarly, Van der Donk et al. (2004) note that the very ease of mobilization may devalue it as a political resource that attracts public 
attention and respect. The internet may also be devalued by activists because it takes the fun and adventure out of some forms of collective protest. Indeed online activism can be seen as lazy politics - it makes people feel good but does very little. It allows like-minded individuals and organizations to talk to each other unfettered by too many social norms and actually do nothing. It can be criticized for further distancing people from each other and deepening already abstract social relations as well as increasing competition between organizations. Kavada (2005) notes that the internet has not led to a greater integration within civil society due to the restrictive policies on external links adopted by civil society organizations and a lack of trust and solidarity. This highlights the fact that new media technology itself does not lead to a brand new age of political collective radicalism.

Solidarity is about engaging beyond the click of a mouse and is about much more than mediation. The performative capacity of solidarity online comes from the felt existence of struggles that are situated in the real material world of poverty, inequality and other social injustices. The concept, and the material experience, of solidarity is steeped in the history of labour relations, struggles and conflicts rooted in the exploitation of labour by the pursuit of capital. It is a modernist concept based on the principles of a political economic order. In this way, solidarity insists on foregrounding the link to the enduring primacy of capitalist relations of production and capitalist imperatives that dominate not only production but consumption and other domains of society and culture. Workers remain exploited by, and struggle against, capitalist orders and capital remains as the hegemonic force. Solidarity also emphasizes that the global reorganization of capital is not a monolithic force of impenetrable power and domination. The notion of mediating solidarity suggests that we should always attend to the dialectical relationship between capital, technology and culture to grasp how new forms of social life and new politics are possible. To understand the present moment we need to interrogate the nature of global technocapitalism and how it is creating a new technoculture and new identities that bring with them threats as well as promises. Further exploration of the concept and materiality of mediated solidarity seems to me to be one way in to this theoretical minefield.

\section{Conclusion}

At the simplest level this article has argued that in analysing the aesthetics and form of popular mobilization online we must attend to 
the political and social context from which it emanated and within which it operates. Directly linked to this, I have also argued that the democratic potential of the internet is not dependent on its primary features. It is realized only through the agents who engage in reflexive and democratic activity. New media can become the location for counter reflexive political deliberation and activity - but only if they embody democratic practice.

I have sought to suggest that the powers of mediation - the ability to communicate to whomsoever you wish as quickly as you desire - are now where the struggles of cultural activism find their home. The use of new communication technology to spread radical social critique and alternative culture is the realm of New Social Movements marked by fragmentation. Fragmentation has been variously interpreted as multiplicity and polycentrality when focusing on the potential for social agency and disaggregation and division when focusing on the potential for increased social control.

Through a consideration of the central themes of multiplicity and polycentrality, interactivity and participation I have argued that the notion of solidarity is key to the future success of popular mobilization and our understanding of it. Solidarity insists on material engagement and goes beyond mediation. It requires mutuality and reciprocity resulting in collective action.

Collective identity has always been a central concern of social movement theorists. Melucci (1996) sees collective identity as a continuous, dynamic and self-reflexive process defined by its multiplicity of interactions, negotiations and conflicts among fellow participants. The internet, relying as it does on a network of networks can assist collective identity and reinforce solidarity. It partakes in the process of meaning construction. The nature and scope of the technology affects not only the way the movement communicates its aims and objectives but also its geographical scale, organizing structure and collective identity. The decentralized, non-hierarchical modes of organizing allow for diverse political agendas and identities to exist. The challenge is how to embrace difference and particularity while also engendering universality and solidarity.

The danger in constructing global solidarity online, as Tarrow (1998) points out, is that the speed at which social movement actors can respond encourages a focus on short term and rapidly shifting issues rather than fully fledged ideologies. This easy-come-easy-go politics does not lend itself to long-standing commitments or deeply held loyalties, but rather to a following that is also fleeting and momentary and often 
lacking in political memory. The ultimate problem that arises from such an approach is how to ensure that open and participatory movements are also effective in influencing public policies and have the possibility of developing a coherent oppositional ideology. Can loose, multi-issue networks progress from a resistance identity to a political project that is sustainable and likely to produce social change? Habermas has argued that solidarity at this level cannot simply be based on shared moral conceptions of human rights but also on a shared political culture (Habermas, 2001: 126). That political culture is constituted not only of social agents who can enable the mediation of dialogue across borders and publics but also of institutions that can translate those claims into a reality.

The issue-and-identity bridging facility of social technologies may explain the organizational capacity of what appears to be a movement with weak collective identity and relatively weak core political agenda. At the same time these defining features of the movement raise questions about other aspects of the movement's political capacity, from communicating clear messages to larger publics, to developing effective relationships with political targets. (Bennett, 2005: 225)

The likelihood of counter political projects emerging rests in part on the ability of localized protest groups to create alliances and organize solidarity locally and globally, as well as on their ability to break away from, penetrate or disrupt the powers of capital. How to build a political movement across borders of geography, identity and subject is a crucial issue for a global economic order that demands critical attention. We need to find ways to build a dialectics of politics that moves freely from the micro to the macro and back again (Harvey, 2000). There is no easy answer, but the concept of mediated solidarity offers an in-road that invites an analysis rooted in structure, agency, technology and culture a critical communications politics of our times.

\section{Notes}

1 Although referring to New Social Movements throughout, this article draws mainly on the various contemporary configurations of global justice movements that have emerged in the last 5-10 years. These mark a distinct shift from the new social movements that developed since the 1960s around issues such as gender and sexual politics, race and ethnicity, peace and the environment that had a strong middle-class basis and contrasted with collective working-class politics that preceded them. Contemporary new social movements include the latter but have also seen a return of protest on material issues of social justice, from the exploitation of child labour by global brands to military interventions by Western 
powers (see Della Porta and Diani, 2006, for a more detailed discussion and analysis).

2 The membership of the G8 has evolved over time to include the US, UK, France, Germany, Italy, Japan, Russia, Canada and the president of the European Union. The first meeting of the G8 focused on macro-economic policy. Now issues of security, trade, relations with developing countries and other transnational and occasionally domestic issues, such as employment, are discussed. The G8 Summits are not a policy-making forum. They are a time for the leaders of states to network and build relationships. The G8 Summits have always been a focus for protests and counter-summits.

\section{References}

Association for Progressive Communications (APC) (2006) URL (consulted March 2006): http://www.apc.org/english/about/index.shtml.

Atton, C. (2004) An Alternative Internet: Radical Media, Politics and Creativity. Edinburgh: Edinburgh University Press.

Bauman, Z. (1997) Postmodernity and its Discontents. Cambridge: Polity.

Benkler, Y. (2006) The Wealth of Networks: How Social Production Transforms Markets and Freedom. London: Yale University Press.

Bennett, W.L. (2004) 'New Media Power: The Internet and Global Activism', in N. Couldry and J. Curran (eds) Contesting Media Power: Alternative Media in a Networked World. Lanham, MD: Rowman \& Littlefield.

Bennett, W.L. (2005) 'Social Movements Beyond Borders: Understanding Two Eras of Transnational Activism', in D. della Porta and S. Tarrow (eds) Transnational Protest and Global Activism, pp. 203-27. Lanham, MD: Rowman \& Littlefield.

Bohman, J. (2004) 'Expanding Dialogue: The Internet, the Public Sphere and the Prospects for Transnational Democracy', in N. Crossley and J.M. Roberts (eds) After Habermas: New Perspectives on the Public Sphere, pp. 131-56. Oxford: Blackwell.

Braidotti, R. (1991) 'The Subject in Feminism', Hypatia 6(2): 155-72.

Breslow, H. (1997) 'Civil Society, Political Economy and the Internet', in S. Jones (ed.) Virtual Culture: Identity and Communication in Cybersociety, pp. 236-57. Thousand Oaks, CA: Sage.

Castells, M. (1996) The Rise of the Network Society. Vol. 1 of The Information Age: Economy, Society and Culture. Oxford: Blackwell.

Cleaver, H. (1999) 'Computer Linked Social Movements and the Global Threat to Capitalism', URL (consulted March 2006): http://www.eco.utexas.edu/faculty/ Cleaver/polnet.html

Crossley, N. (2002) 'Global Anti-Corporate Struggle: A Preliminary Analysis', British Journal of Sociology 53(4): 667-91.

Della Porta D. (2005) 'Multiple Belongings, Tolerant Identities and the Construction of "Another Politics": Between the European Social Forum and the Local Social fora', in D. della Porta and S. Tarrow (eds) Transnational Protest and Global Activism. Lanham, MD: Rowman \& Littlefield.

Della Porta, D. and Diani, M. (1999) Social Movements: An Introduction. Oxford: Blackwell.

Della Porta, D. and Diani, M. (2006) Social Movements: An Introduction, 2nd edn. Oxford: Blackwell. 
Della Porta, D. and Tarrow, S. (eds) (2005) Transnational Protest and Global Activism. Lanham, MD: Rowman \& Littlefield.

Diani, M. (2001) 'Social Movement Networks. Virtual and Real', in F. Webster Culture and Politics in the Information Age, pp. 117-27. London: Routledge.

Downey, J. and Fenton, N. (2003) 'Constructing a Counter-Public Sphere', New Media and Society (5)2: 185-202.

Dyer-Witheford, N. (1999) Cyber-Marx: Cycles and Circuits of Struggle in High Technology Capitalism. Illinois: University of Illinois Press.

Fenton, N. (2000) 'The Problematics of Postmodernism for Feminist Media Studies', Media, Culture and Society 22(6): 723-41.

Fenton, N. and Downey, J. (2003) 'Counter Public Spheres and Global Modernity', Javnost - The Public (X)1: 15-33.

Gamson, W. (1990) The Strategy of Social Protest, 2nd edn. Belmont, CA: Wadsworth.

Habermas, J. (1989) The Structural Transformation of the Public Sphere: An Inquiry into a Category of Bourgeois Society. Cambridge: Polity.

Habermas, J. (1992) 'Further Reflections on the Public Sphere', in C. Calhoun (ed.) Habermas and the Public Sphere, pp. 421-61. Cambridge, MA: MIT Press.

Habermas, J. (1998) Inclusion of the Other: Studies in Political Theory. Cambridge: Polity.

Habermas, J. (2001) The Postnational Constellation. Cambridge, MA: MIT Press.

Harvey, D. (2000) Spaces of Hope. Edinburgh: Edinburgh University Press.

Hill, K. and Hughes, J. (1998) Cyberpolitics: Citizen Activism in the Age of the Internet. Lanham, MD: Rowman \& Littlefield.

Jordon, T. and Taylor, P. (2004) Hacktivism and Cyberwars: Rebels without a Cause? London: Routledge.

Kavada, A. (2005) 'Civil Society Organizations and the Internet: The Case of Amnesty International, Oxfam and the World Development Movement', in Wilma de Jong, Martin Shaw and Neil Stammers (eds) Global Activism, Global Media, pp. 208-23. London: Pluto.

Keck, M.E and Sikkink, K. (1998) Activists Beyond Borders: Advocacy Networks in International Politics. New York: Cornell University Press.

Klein, N. (2000) No Logo. New York: Flamingo.

Klein, N. (2002) Fences and Windows: Dispatches from the Front Lines of the Globalization Debate. London: Flamingo.

Mansbridge, J. (2001) 'Complicating Oppositional Consciousness', in J. Mansbridge and A. Morris (eds) Oppositional Consciousness: The Subjective Roots of Social Protest, pp. 238-64. Chicago, IL: University of Chicago Press.

Melucci, A. (1996) The Playing Self. Cambridge: Cambridge University Press.

Mouffe, C. (ed.) (1992) Dimensions of Radical Democracy; Pluralism, Citizenship, Community. London: Verso.

Mouffe, C. (1993) The Return of the Political. London: Verso.

Negt, O. and Kluge, A. (1972) Public Sphere and Experience: Towards an Analysis of the Bourgeois and Proletarian Public Sphere. Minneapolis: University of Minnesota Press.

Norris, P. (2002) Democratic Phoenix: Reinventing Political Activism. Cambridge: Cambridge University Press.

People's Gobal Action (PGA) (2006) URL (consulted March 2006): http://www.nadir.org/nadir/initiativ/agp/en/pgainfos/history.htm.

Rheingold, H. (2002) Smart Mobs: The Next Social Revolution. Cambridge, MA: Perseus Publishing. 
Salter, L. (2003) 'Democracy, New Social Movements and the Internet: A Habermasian Analysis', in M. McCaughey and M.D. Ayers (eds) Cyberactivism: Online Activism in Theory and Practice. London: Routledge.

Sassen, S. (2005) 'Electronic Markets and Activist Networks: The Weight of Social Logics in Digital Formations', in R. Latham and S. Sassen (eds) Digital Formations: New Architectures for Global Order, pp. 54-88. Princeton, NJ: Princeton University Press.

Schiller, Herbert (1989) Culture Inc.: The Corporate Takeover of Public Expression. Oxford: Oxford University Press.

Spivak, G. (1992) 'French Feminism Revisited: Ethics and Politics', in J. Butler and J. Scott (eds) Feminists Theorize the Political. London: Routledge.

Sunstein, C. (2001) Republic.com. Princeton, NJ: Princeton University Press.

Tarrow, S. (1998) Power in Movement - Social Movements and Contentious Politics. Cambridge: Cambridge University Press.

Tomlinson, J. (1999) Globalization and Culture. Cambridge: Polity.

Van der Donk, W., Loader, B.D., Nixon, P.G. and Rucht, D. (eds) (2004) Cyberprotest: New Media, Citizens and Social Movements. London: Routledge.

Waters, M. (1995) Globalization. London: Routledge.

World Energy Outlook (2002) 'World Energy Outlook 2002: Executive Summary', URL (consulted June 2005): http://www.worldenergy.org/wecgeis/publications/statements/ stat2002.asp

Zhao, Y. (2003) 'Falun Gong, Identity and the Struggle over Meaning Inside and Outside China', in N. Couldry and J. Curran (eds) Contesting Media Power: Alternative Media in a Networked World. Lanham, MD: Rowman \& Littlefield.

\section{Biographical note}

Natalie Fenton is a senior lecturer in the Department of Media and Communication at Goldsmiths College, University of London. She is Co-Director of Goldsmiths Media Research Programme and Co-Director of Goldsmiths Centre for the Study of Global Media and Democracy.

Address: Department of Media and Communication, Goldsmiths College, University of London, New Cross, London, SE14 6NW. [email: n.fenton@gold.ac.uk] 